\title{
Assessment of culturable airborne bacteria of indoor environments in classrooms, dormitories and dining hall at university: a case study in China
}

\author{
Yanju Li $\mathbb{D} \cdot$ Yanhui Ge $\cdot$ Chunbin Wu Dexing Guan · Jinbao Liu • \\ Fuyang Wang
}

Received: 7 August 2019/Accepted: 21 February 2020/Published online: 2 March 2020

(C) Springer Nature B.V. 2020

\begin{abstract}
University students' health may be adversely affected by exposure to indoor bacterial contaminants on their campuses. This study aims (1) to quantify culturable bacterial concentrations in three indoor environments at a university, (2) to investigate the influence of meteorological factors and gender, to assess the relationship between indoor and outdoor, and (3) to estimate the bacterial dose for university students in different indoor environments. Airborne bacteria samples were collected in 12 classrooms, in 12 living rooms and four bathrooms in two dormitory buildings, and in a dining hall. The results showed that the microenvironment in the female dormitory had the highest mean bacterial concentration $\left(2847 \mathrm{CFU} / \mathrm{m}^{3}\right)$, whereas the lowest mean bacterial concentration was observed in classrooms $\left(162 \mathrm{CFU} / \mathrm{m}^{3}\right)$. Indoor bacterial concentrations in male dormitories were significantly lower than in female dormitories probably because of crowding and increased ventilation. Outdoor weather conditions were associated with the
\end{abstract}

Yanju Li and Yanhui Ge have equally contributed to this work.

Y. Li ( $₫) \cdot$ C. Wu · D. Guan

School of Energy and Safety Engineering, Tianjin

Chengjian University, Tianjin, China

e-mail: lyj2_18@126.com

Y. Ge $(\bowtie) \cdot$ J. Liu $\cdot$ F. Wang

School of Environmental Science and Safety Engineering,

Tianjin University of Technology, Tianjin, China

e-mail: geyanhui@tjut.edu.cn indoor concentrations with regard to insufficient ventilation and varying outdoor concentration. The occupants' activity level was also more closely related to the indoor bacteria concentration in the residential setting. Students experienced about four times higher dose of airborne bacteria in the dormitories than in the classrooms and dining hall.

Keywords Indoor environment - Bacterial contaminant $\cdot \mathrm{I} / \mathrm{O}$ ratio $\cdot$ Gender $\cdot$ Dose of airborne bacteria

\section{Introduction}

Currently, people spend more than $90 \%$ of their time in indoor environments (Klepeis et al. 2001), and increasing attention has been attracted to the assessment of indoor biological pollutants since the increasing of sick building syndrome (Sahlberg et al. 2013) and building-related illnesses (Squinazi 1990) and the outbreak of severe acute respiratory syndrome (SARS) and avian influenza. There is growing evidence that indoor airborne bacteria, or bioaerosols, as a major factor in human health and comfort according to numerous epidemiological studies (Ege et al. 2011; Mendell et al. 2011; Madureira et al. 2015; Heinrich 2011; Yu et al. 2011; Keski-Nisula et al. 2009) are widely present in indoor environments (Despré et al. 2012). 
In recent years, over seven million students have graduated annually from universities in China. Studies have characterized the indoor environment as crucial to students' health and academic performance (Mendell and Heath 2005; Daisey et al. 2003). With higher occupant density and more crowded campuses, the potential for contact with biological pollutants and their transmission among infected students may be greater at Chinese universities than at universities in other developed countries. Therefore, assessment of indoor biological contaminants on university campuses has become extremely important in China. Numerous studies have evaluated the levels of airborne bacteria in various indoor environments at universities: classrooms (Bhangar et al. 2014; Qian et al. 2012; Chatzidiakou et al. 2012; Grisoli et al. 2012), archives (Nunes et al. 2013), libraries (Hayleeyesus and Manaye 2014; Kalwasinska et al. 2012), dormitory rooms (Hayleeyesus et al. 2015) and laboratories (Giulio et al. 2010; Priyamvada et al. 2018). Each of the above-mentioned studies on indoor airborne bacteria at universities focused mainly on a single type of environment. Few studies have evaluated bioaerosol concentrations in multiple indoor environments and assessed the pollutant levels across these environments ( $\mathrm{Li}$ et al. 2015; Chan et al. 2008).

It has been demonstrated that the level and distribution of indoor bacterial concentration vary greatly and are influenced by many factors, such as peak traffic, pollutants from factories, occupancy, human activity, indoor flooding, and outdoor bacteria that are drawn in through the ventilation system (Godwin and Batterman 2007; Emerson et al. 2015; Luongo et al. 2016b; Meadow et al. 2014; Heo et al. 2017). Generally, the relationship between indoor and outdoor bacterial concentration (I/O ratio) has been considered an important index for evaluating the indoor bacterial concentration on various indoor concentrations. $\mathrm{Li}$ et al. (2015) reported that the I/O ratios for airborne bacteria were greater than 1 in a dining hall, a clinic and a dormitory, but not in classrooms. Kim and Kim (2007) found that I/O ratios for airborne bacteria ranged from 0.26 to 0.71 in tested buildings. The I/O ratios reported by Balasubramanian et al. (2012) ranged widely, from 0.43 to 11.8 . Thus, there is no clear conclusion about the factors that influence indoor bacterial levels, or the relationship between indoor and outdoor concentration.
In addition, the effects of exposure to indoor airborne bacteria on personal health are related not only to the concentration and residence time, but also to human body characteristics. Existing studies on exposure to indoor contaminants were conducted with an index known as the dose rate. For example, Castro et al. (2011) assessed the health risks of gas and particulate matter generated by tobacco smoke in indoor environments and determined the dose rates of the gas and particles. A similar study by Fonseca et al. (2014) employed the dose rate to assess ultrafine particles in preschools. Recently, Madureira et al. (2015) used the dose rate to investigate the health risk of indoor airborne bioaerosols. Furthermore, because of the infectious nature and diversity of biological pollutants, bioaerosol exposure in the indoor environment should be studied in greater depth. Moreover, most of the above-mentioned studies on exposure to indoor contaminants by dose rate were focused on particles and chemical components, while exposure to airborne bacteria has been investigated less frequently.

The objective of the present study was to evaluate indoor airborne bacterial concentrations in typical indoor environments at a university (classrooms, dormitories and dining halls). The specific aims of the current study were (1) to quantify culturable bacterial concentrations considered to potentially harmful to students in three different indoor environments at the university, (2) to investigate the influence of meteorological factors and gender on indoor bacterial concentrations, and to assess the relationship between outdoor bacterial concentration and indoor concentration, and (3) to estimate the bacterial dose by which university students possibly expose, in different portions of same building.

\section{Methods and materials}

\subsection{Sampling site}

All experiments were conducted on a university campus in an urban area in Tianjin, Northeast China. Airborne bacteria data were collected in 12 classrooms (four of which had a seating capacity of about 200 students, four with a capacity of over 160, and four with a capacity of over 100) on three different floors in the academic building (activities: leaning, writing, reviewing and so on); 12 dormitories (activities: 
cleaning, walking, sleeping and so on) and four bathrooms (i.e., 12 living/sleeping rooms and four bathrooms in building A (female dormitory) and building B (male dormitory)), where each living/ sleeping room had an area of about $16 \mathrm{~m}^{2}$; and a threestory dining hall $(68.4 \mathrm{~m}$ (length) $\times 36 \mathrm{~m}$ (width)) (activities: eating, walking and so on). The selected classrooms were equipped with standard furniture, the dormitory rooms each contained two sets of bunk beds, and general seats and tables were placed in the dining hall (Fig. 1). The cleaning procedures of the teaching building and dining hall were made by cleaning company with the same type of products, while the cleaning procedures of dorms were made by students. All the sampling sites under investigation were naturally ventilated by opening windows and doors, and heated by a radiator system that was in operation during the heating period (from November 15 to March 15 of the following year). The layout of the university campus and the measured indoor environments is shown in Fig. 1.

The airborne bacteria in the classrooms, dormitories and dining hall were investigated at autumn term to spring term in a year when the students stayed at university, and the experiments were not carried out in holidays. The outdoor environments of the tested

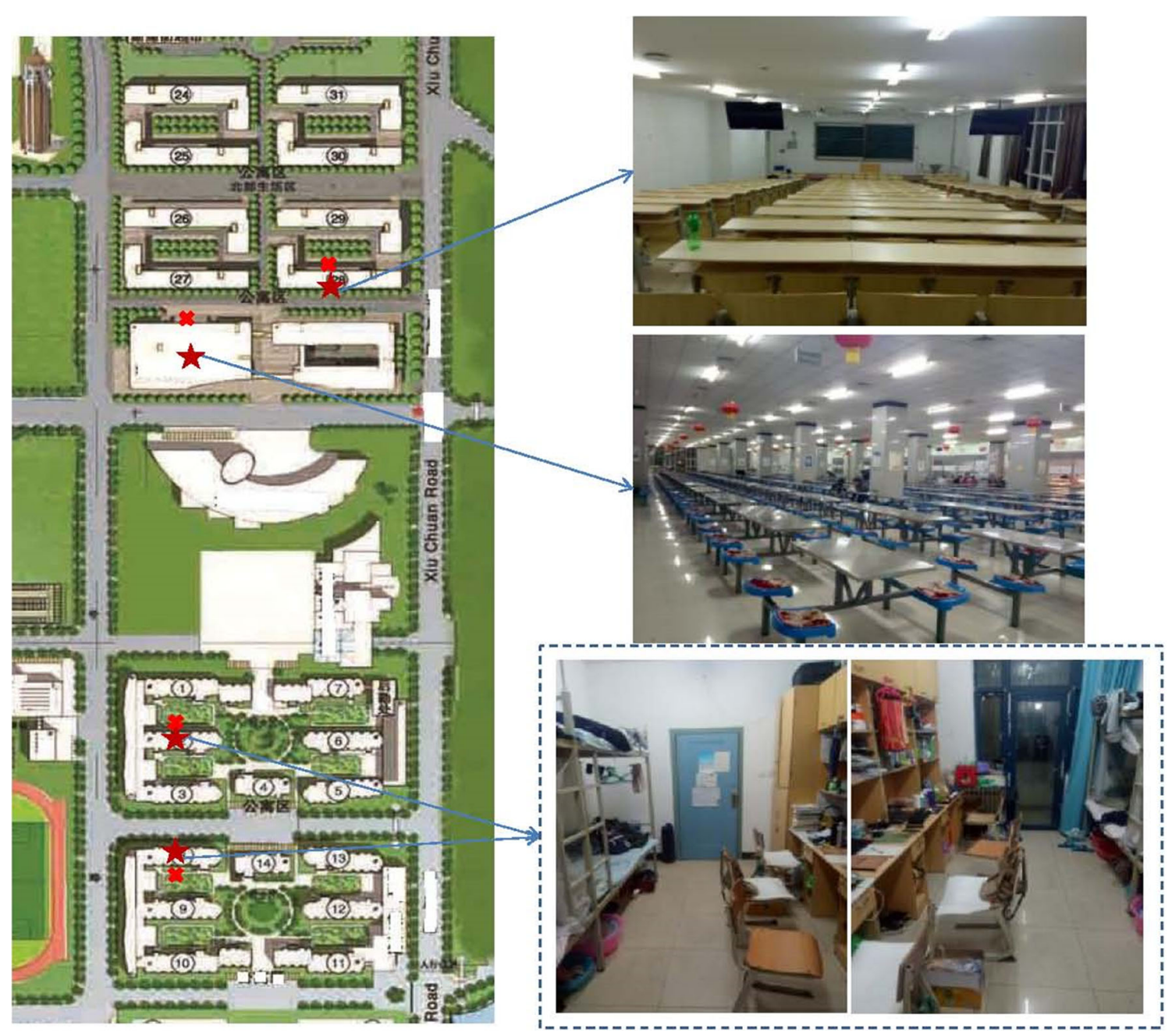

(a)

(c)

Fig. 1 Layout of the university campus and representative locations for measurement of indoor environments (a classroom, b dining hall, c dormitory; $\boldsymbol{*}$ the sampling position of outdoor air) 
Table 1 Characteristics of the classrooms, dormitories and dining hall: description, series, floor area, windows/doors, orientation, and outdoor environment

\begin{tabular}{|c|c|c|c|c|c|c|c|}
\hline Building & Description & Series & & $\begin{array}{l}\text { Floor } \\
\text { area } \\
\left(\mathrm{m}^{2}\right)\end{array}$ & Windows/doors & Orientation & $\begin{array}{l}\text { Outdoor } \\
\text { environment }\end{array}$ \\
\hline \multirow{12}{*}{$\begin{array}{r}\text { Academic } \\
\text { building }\end{array}$} & \multirow{12}{*}{$\begin{array}{l}\text { Four-story academic building with a } \\
\text { lecture hall on the ground floor and } \\
\text { general classrooms on the other } \\
\text { floors. }\end{array}$} & \multirow{4}{*}{$\begin{array}{l}\text { Ground } \\
\text { floor }\end{array}$} & A11 & 208 & $3 / 2$ & $\mathrm{~S}$ & \multirow{12}{*}{$\begin{array}{l}\text { Planted and } \\
\text { near a } \\
\text { sidewalk }\end{array}$} \\
\hline & & & A12 & 175 & $3 / 2$ & $\mathrm{~S}$ & \\
\hline & & & A13 & 182 & $3 / 2$ & $\mathrm{~N}$ & \\
\hline & & & A14 & 238 & $3 / 2$ & $\mathrm{~N}$ & \\
\hline & & \multirow[t]{4}{*}{ 1st floor } & A21 & 128 & $6 / 2$ & $\mathrm{~S}$ & \\
\hline & & & A22 & 125 & $6 / 2$ & $\mathrm{~S}$ & \\
\hline & & & A23 & 148 & $6 / 2$ & $\mathrm{~N}$ & \\
\hline & & & A24 & 143 & $6 / 2$ & $\mathrm{~N}$ & \\
\hline & & \multirow{4}{*}{$\begin{array}{l}\text { 3rd } \\
\text { floor }\end{array}$} & A41 & 128 & $6 / 2$ & $\mathrm{~S}$ & \\
\hline & & & A42 & 125 & $6 / 2$ & $\mathrm{~S}$ & \\
\hline & & & A43 & 148 & $6 / 2$ & $\mathrm{~N}$ & \\
\hline & & & A44 & 143 & $6 / 2$ & $\mathrm{~N}$ & \\
\hline \multirow{8}{*}{$\begin{array}{l}\text { Male/female } \\
\text { dormitories }\end{array}$} & \multirow{8}{*}{$\begin{array}{l}\text { Two identical six-story dormitories, } \\
\text { with } 25 \text { rooms, } 2 \text { toilets and } 2 \\
\text { bathrooms (WR) on each floor }\end{array}$} & \multirow{8}{*}{$\begin{array}{l}\text { Male/ } \\
\text { female }\end{array}$} & 113 & 16 & $1 / 1$ & $\mathrm{~S}$ & \multirow{8}{*}{$\begin{array}{l}\text { Well cared } \\
\text { for } \\
\text { gardens }\end{array}$} \\
\hline & & & 119 & 16 & $1 / 1$ & $S$ & \\
\hline & & & 128 & 16 & $1 / 1$ & $\mathrm{~S}$ & \\
\hline & & & 102 & 16 & $1 / 1$ & $\mathrm{~N}$ & \\
\hline & & & 105 & 16 & $1 / 1$ & $\mathrm{~N}$ & \\
\hline & & & 110 & 16 & $1 / 1$ & $\mathrm{~N}$ & \\
\hline & & & WR1 & 20 & $2 / 1$ & $\mathrm{~N}$ & \\
\hline & & & WR2 & 20 & $2 / 1$ & $\mathrm{~N}$ & \\
\hline Dining hall & $\begin{array}{l}\text { Three stories, of which the ground and } \\
\text { first floors were serviced for } \\
\text { students, while the second floor was } \\
\text { divided into small rooms for other } \\
\text { persons }\end{array}$ & $\begin{array}{l}\text { Ground } \\
\text { floor }\end{array}$ & $\begin{array}{r}\text { Student } \\
\text { dining } \\
\text { rooms }\end{array}$ & 2460 & $22 / 4$ & - & $\begin{array}{l}\text { Planted and } \\
\text { at a cross } \\
\text { of two } \\
\text { roads }\end{array}$ \\
\hline
\end{tabular}

buildings were planted or well cared as gardens. The cutting of the grass in the gardens or land movement has not been carried out during sampling. The details of the selected locations are provided in Table 1.

\subsection{Sampling method and materials}

Because of the large area and numerous sampling points in the selected locations, the natural sedimentation method (NS method, also known as the settle plate method) (Faridi et al. 2015; Liu et al. 2019) was adopted as the sampling method in this research. The airborne bacteria in the selected classrooms were tested at 7:40 am (before the first lecture), 9:50 am (after the first lecture) and 11:50 am (after the second lecture). For the dormitories, the times of 9:00, 13:00 and 20:00 were chosen as the sampling times for a typical day. Meanwhile, the biological contaminant concentration in the dining hall was measured at 10:00 (after breakfast), 12:40 (lunchtime), and 15:00 (before dinner) during the typical day. The sampling plates (90 $\mathrm{mm}$ diameter, three replicate plates at one sampling site) were placed on a desk or table at a distance of $0.8 \mathrm{~m}$ above the ground in the classrooms and dining hall, and directly on the ground in the dormitories for layout of dorms with the furniture placed by the side of room and empty in middle of room. The outdoor sites were located next to the selected rooms, at window height and away from the wall $1.0 \mathrm{~m}$ with three plates in triplicates. To avoid the influence of outdoor wind, the sampling plates were fixed in a shallow box with opening skylight (Fig. 2). 


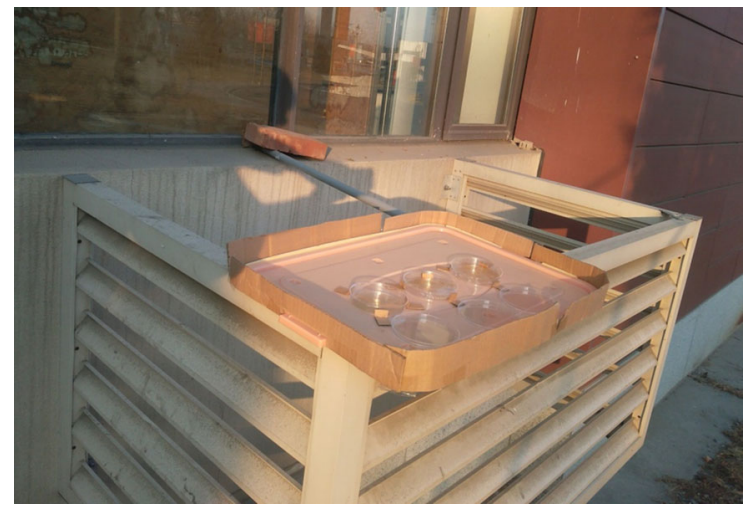

Fig. 2 The sampling plates of outdoor in an open shallow box

Table 2 The nominal weather condition of outdoor at the sampling days

\begin{tabular}{|c|c|c|}
\hline & Sampling time & General description \\
\hline \multirow[t]{2}{*}{ Normal } & Autumn term & $\begin{array}{l}\text { Calm and sunny } \\
\text { Temp } 10{ }^{\circ} \mathrm{C} /-9{ }^{\circ} \mathrm{C} \\
\text { RH } 32.1-68.5 \% \\
\text { WS } 3.4-7.9 \text { or }<3.4 \\
\text { WD: northwest or northeast }\end{array}$ \\
\hline & Spring term & $\begin{array}{l}\text { Calm and sunny } \\
\text { Temp } 30{ }^{\circ} \mathrm{C} / 16{ }^{\circ} \mathrm{C} \\
\text { RH } 52.7-62.2 \% \\
\text { WS } 3.4-7.9 \text { or }<3.4 \\
\text { WD: southeast }\end{array}$ \\
\hline \multicolumn{2}{|c|}{ Special climate day } & $\begin{array}{l}\text { Snowy } \\
\text { Temp }-8{ }^{\circ} \mathrm{C} /-1{ }^{\circ} \mathrm{C} \\
\text { RH } 60.2-68.5 \% \\
\text { WS 1.6-3.4 } \\
\text { WD: northwest } \\
\text { Windy } \\
\text { Temp } 4{ }^{\circ} \mathrm{C} /-2{ }^{\circ} \mathrm{C} \\
\text { RH } 43.9-49.2 \% \\
\text { WS } 8.0-13.8 \text { or }>13.8 \\
\text { WD: northwest }\end{array}$ \\
\hline
\end{tabular}

Details of the outdoor climate description in the sampling days are listed in Table 2. Meteorological data (T, RH, WS, WD) are from weather China forecast (1-h update) of urban station and the multifunction ventilation meter (TSI 9565, US). The samples of temperature and RH were collected for $5 \mathrm{~min}$ by TSI 9565. The general description, temperature (Temp), relative humidity $(\mathrm{RH})$, wind speed (WS) and wind direction (WD) of the ambient outdoor environment were also recorded, and the average values are provided (Table 2).

Three sampling plates were placed at each sampling point and opened for $5 \mathrm{~min}$ of exposure (NSC 2013). The plates were then collected and cultivated at $37{ }^{\circ} \mathrm{C}$ for $48 \pm 3 \mathrm{~h}$ (Kim et al. 2007). Bacteria were counted by the naked eye in accordance with the methods explained in ISO 4833 (2013). Each sampling point had three plates (prepared before use) coated with 15-ml nutrient broth agar (3.0 g beef extract, $10.0 \mathrm{~g}$ peptone and $5.0 \mathrm{~g} \mathrm{NaCl}$ in $1000 \mathrm{ml}$ distilled water) and sterilized for $20 \mathrm{~min}$ at $121{ }^{\circ} \mathrm{C}$. The number of sampling points placed by triangle rule in each room was determined by the area of the room (approximately one point per $30 \mathrm{~m}^{2}$ ) (NSC 2002). Meanwhile, avoiding the accidental contamination during the experiments, three identical plates without sampling were used a negative control in each experiment, which is made by the same procedure (sterilize, coated with 15-ml nutrient broth agar, cultivated) except for sampling.

The concentrations of indoor and outdoor airborne bacteria can be expressed as the number of colonyforming units and calculated by means of the Omeliansky function (Omeliansky 1940; Hayleeyesus et al. 2015), which is expressed by Eq. (1).

$c=N /\left(\frac{A}{100} \times \frac{t}{5} \times \frac{10}{1000}\right)=\frac{N \times 50000}{A \times t}$

where $C$ is the bacterial concentration (colony-forming units per cubic meter $\left.(\mathrm{CFU}) / \mathrm{m}^{3}\right), N$ is the average number of CFU on three plates, $A$ is the plate area $\left(\mathrm{cm}^{2}\right)$, and $t$ is the exposure time (min).

\subsection{Dose rate}

The dose rate is defined by Eq. (2), which had been verified in previously reported studies (Madureira et al. 2015; Fonseca et al. 2014; Castro et al. 2011):

$\mathrm{DR}=\left(\frac{\mathrm{BR}_{\mathrm{Wa}}}{\mathrm{BW}}\right) \times C_{\mathrm{Wa}} \times \mathrm{OF} \times N$

where DR is the age-specific dose rate, CFU/ $\mathrm{kg} / \mathrm{day}$; $\mathrm{BR}_{\mathrm{Wa}}$ is the age-specific weighted average breathing rate, $\mathrm{L} / \mathrm{min}$; $\mathrm{BW}$ is the body weight of the university student, $\mathrm{kg} ; C_{\mathrm{Wa}}$ is the weighted average bacterial 
concentration (tested bacteria concentration in selected indoor environments), CFU/L; OF is the occupancy factor; $N$ is the total time per day spent in the location of exposure, min/day. The daily activity patterns of university students (including studying time, dinner time and dormitory time) were recorded and analyzed. The $\mathrm{BR}_{\mathrm{Wa}}$ is determined by the intensity of the activity during the exposure time. $\mathrm{BR}_{\mathrm{Wa}}$ of the students was indexed as $5.8 \mathrm{~L} / \mathrm{min}$ (male), and $4.8 \mathrm{~L} /$ min (female) for sedentary activity, and $13.4 \mathrm{~L} / \mathrm{min}$ (male), and $11.1 \mathrm{~L} / \mathrm{min}$ (female) for light-intensity activity. $\mathrm{BR}_{\mathrm{Wa}}$ values (male and female combined) of 5.3 L/min and $12.0 \mathrm{~L} / \mathrm{min}$ were used for sedentary and light-intensity activity, respectively. (Since the students in this study usually spent their time sitting (e.g., writing, reading, drawing), eating, or sleeping, their activities were classified as "sedentary/passive" or "light intensity." Age-specific inhalation factors (male, female or combined) were obtained from the US EPA exposure factors handbook (US EPA 2011) since no systemic data concerning the Chinese population were available in the literature.) The $C_{\mathrm{Wa}}$ was based on the median bacterial concentration, and the OF was specified as 1 because of the close relationship between the students' schedules and their respective locations. During their classes, the students had similar schedules and activity patterns, spending about $8 \mathrm{~h}$ per day in classrooms, with a sedentary level for both males and females. Overall, the students were sedentary for $9 \mathrm{~h}$ per day (in the dormitories) and engaged in light-intensity activities for $2 \mathrm{~h}$ (in the dining halls).

\subsection{Statistical analysis}

The mean value and standard deviation of bacterial concentration were calculated with the use of Microsoft Excel software. The statistically significant differences were determined for analysis of the experimental results using SPSS software. Statistical significance was defined as $p<0.05$.

\section{Results and discussion}

\subsection{Airborne culturable bacterial concentration in the investigated environments}

Table 3 summarizes the average (with standard deviation) maximum (max) and minimum (min) values of the indoor and outdoor airborne bacterial concentrations at the tested university, including the classrooms on the selected floors (the ground, first and third), the dormitories, and the dining halls. The mean and SD (standard deviation) of temperature of the tested indoor environments was $18.4 \pm 2.1{ }^{\circ} \mathrm{C}$ (range of $16.0-23.1^{\circ} \mathrm{C}$ ), and that of relative humidity was $44.7 \pm 8.1 \%$ (ranged from 35.1 to $60.0 \%$ ). The concentration of indoor airborne bacteria varied greatly among the three types of indoor environment. As a result, as shown by a comparison of the three indoor types, the mean bacterial concentration was highest in the dormitories and lowest in the classroom on the ground floor. One possible explanation for this observation may be the more crowded and higher activity level of the students in the dormitories. This prediction is also supported by previous studies in which human activities were found to affect the airborne microbial concentration by means of resuspension (Kim and Kim 2007; Mentese et al. 2009). In addition, by comparing the concentration of bacteria in school dormitories and nursing homes, Faridi et al. (2015) found that the concentration of bacteria in nursing old homes was higher, with the explanation of incapability to maintain their personal hygiene for older people. Similar reasons of our study, with regularly disinfected twice a week for canteen and no regulative activities in dormitory, resulted in the lower bacterial concentration of the canteen than that of the dormitory.

On average, hundreds of indoor air bacteria were counted in the classrooms on the three floors $\left(162 \pm 140,594 \pm 405,247 \pm 157 \mathrm{CFU} / \mathrm{m}^{3}\right)$, and similar average bacteria counts (several hundreds) have been observed in classrooms at Chang'an University $\left(479 \pm 66 \mathrm{CFU} / \mathrm{m}^{3}\right)(\mathrm{Li}$ et al. 2015) and in Turkey $\left(618 \pm 812 \mathrm{CFU} / \mathrm{m}^{3}\right)$ (Mentese et al. 2009). Further analysis showed no statistically significant differences in the bacterial concentration in the classrooms among the different floors $(p<0.05)$. For evaluation of the level of contamination by indoor bacteria in the dormitories, the bacterial concentration 
Table 3 Mean (and standard deviation), maximum (Max), and minimum (Min) values of the indoor and outdoor airborne bacteria concentration in the tested environments $\left(\mathrm{CFU} / \mathrm{m}^{3}\right)$

\begin{tabular}{|c|c|c|c|c|c|c|c|}
\hline \multirow[t]{2}{*}{ Locations } & & \multicolumn{2}{|l|}{$C \pm s$} & \multicolumn{2}{|l|}{ Max } & \multicolumn{2}{|l|}{ Min } \\
\hline & & Indoor & Outdoor & Indoor & Outdoor & Indoor & Outdoor \\
\hline \multirow[t]{3}{*}{ Classrooms } & Ground floor & $162 \pm 140$ & $3019 \pm 1725$ & 1363 & 5924 & 52 & 524 \\
\hline & 1st floor & $594 \pm 405$ & $7289 \pm 4642$ & 2411 & 17,352 & 52 & 1992 \\
\hline & 3rd floor & $247 \pm 157$ & $8495 \pm 8631$ & 734 & 32,188 & 52 & 1887 \\
\hline \multirow[t]{2}{*}{ Dorms } & Male & $1956 \pm 3407$ & $6806 \pm 6575$ & 19,514 & 20,235 & 157 & 1101 \\
\hline & Female & $2847 \pm 2554$ & $8589 \pm 8101$ & 13,001 & 25,635 & 105 & 891 \\
\hline Dining hall & Ground floor & $513 \pm 311$ & $3853 \pm 1697$ & 1678 & 6448 & 105 & 1468 \\
\hline
\end{tabular}

$C$ is the mean concentration of all sampling positions, and $s$ is the standard deviation. Twenty-nine sampling points were designated in the tested areas

in the dorms was compared with the results of previous field studies. The average bacterial concentrations in the 12 tested dormitory rooms are listed in Table 3. The indoor biological concentrations were $2.847 \pm 2.554 \times 10^{3}$ and $1.956 \pm 3.407 \times$ $10^{3} \mathrm{CFU} / \mathrm{m}^{3}$, respectively, measured in the dormitory rooms of female and male students. The mean airborne bacterial concentrations indoors were similar with the value $\left(2345 \mathrm{CFU} / \mathrm{m}^{3}\right.$ ) observed in a field study by Hayleeyesus et al. (2015). However, the minimum bacterial concentrations were lower than that reported by Hayleeyesus et al. (2015). This difference was due to the more number of students (4-26) per room in their study, compared with 1-5 persons in the present study. Because of leftover food that was present during the sampling process, a field study by Li et al. (2015) found that the indoor bacterial concentration was $1025 \mathrm{CFU} / \mathrm{m}^{3}$ in a dining hall, about two times the values in this study. Even though no reasonable comparison with the standard limited value was conducted in this study for the different sampling methods, the results indicate an acceptable level of exposure to indoor airborne bacteria $\left(2500 \mathrm{CFU} / \mathrm{m}^{3}\right.$, the threshold value for biological contaminant concentration in standard of China) (NSC 2002) during the testing period, with the exception of five of the dormitory rooms.

However, the outdoor bacterial concentrations in this study (several thousands $\mathrm{CFU} / \mathrm{m}^{3}$ ) were far larger than those indoors as well as the indoor concentration in a previous field study $\left(532 \pm 643 \mathrm{CFU} / \mathrm{m}^{3}\right)$ (Mentese et al. 2009). Similarly, as shown in Table 3, the average indoor bacterial concentration measured in the dining hall $\left(513 \pm 311 \mathrm{CFU} / \mathrm{m}^{3}\right)$ was lower than the outdoor concentration $\left(3853 \pm 1697 \mathrm{CFU} / \mathrm{m}^{3}\right)$. Further analysis of the data demonstrated that there were statistically significant differences in between indoor and outdoor bacterial concentration in the tested dining hall at $a>95 \%$ confidence level.

\subsection{Effects of meteorological factors on indoor bacterial concentration}

In three different types of weather (sunny, windy and snowy), measurements were conducted in four classrooms (two with southern exposure, two northern), with five sampling points in each classroom. The average indoor bacterial concentrations in the selected classrooms, measured at 7:00 (students entering, T1), 9:40 (the break of two lessons T2) and 11:40 (after class, T3), are displayed in Fig. 3. The average concentration of indoor bacteria during windy weather (ranging from $1.40 \times 10^{3}$ to $2.08 \times 10^{3} \mathrm{CFU} / \mathrm{m}^{3}$ ) was the highest among the three types of weather. The indoor bacterial concentration during sunny weather remained at the same level (about $0.5 \times 10^{3} \mathrm{CFU} / \mathrm{m}^{3}$ ) of the indoor concentration during snowy weather at tested times (Fig. 3). At $a>95 \%$ confidence level, further analysis of the data indicated statistically significant differences in the sunny-windy and windysnowy comparisons, but not in the sunny-snowy comparison. Possible causes for these findings may be the greater air change when natural ventilation was enhanced during windy weather, and the higher outdoor bacterial counts related to the meteorological factors of cloudiness and wind speed (Mentese and 


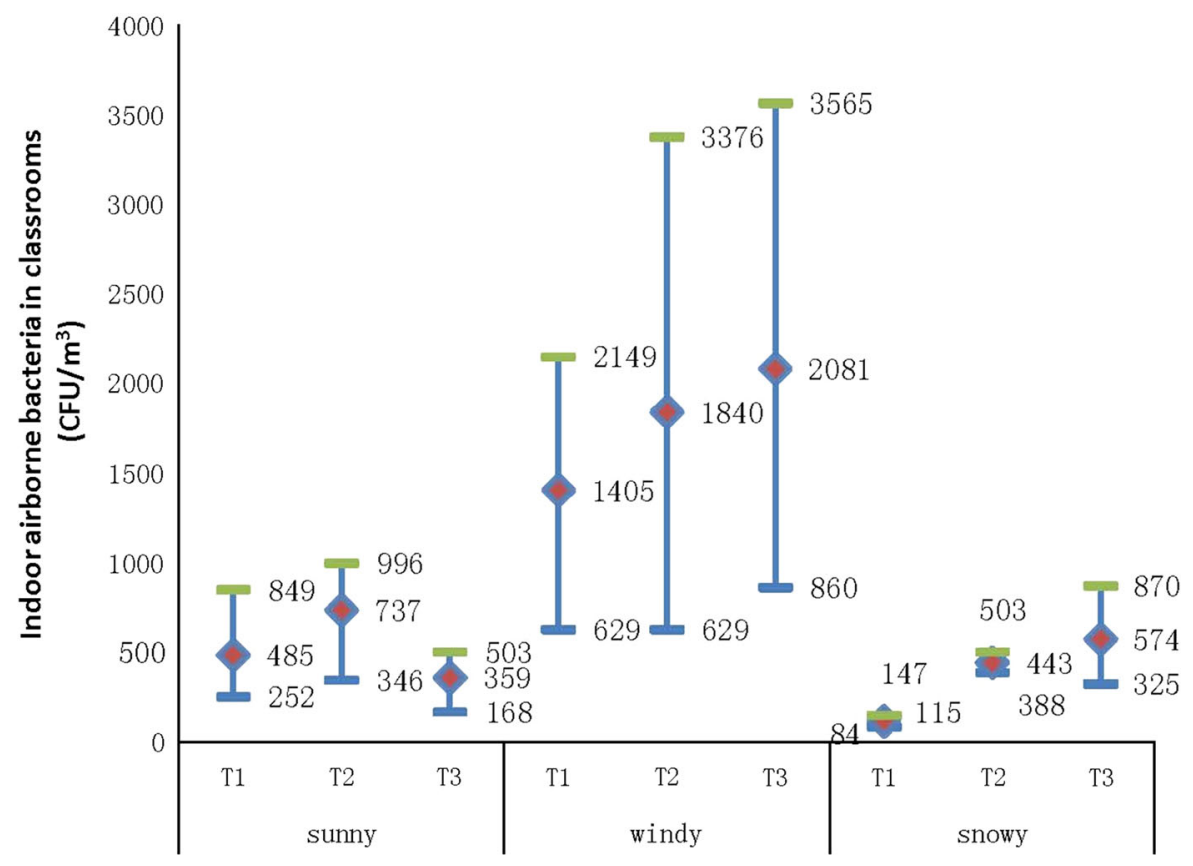

Fig. 3 High, average, and low bacterial concentrations (CFU/ $\mathrm{m}^{3}$ ) in classrooms on the first floor during sunny, windy and snowy weather at different sampling times (T1-7:00 (students entering), T2-09:40 (the break of two lessons), T3-11:40

Tasdibi 2014). According to the tested results, the temperature of outdoor varied less than that of indoor during the sampling period, and higher $\mathrm{RH}$ of outdoor $(68.5 \%)$ was gained than that of indoor $(35.1 \%)$ without humidifier in snowy day. On the other hand, weather conditions are closely related to outdoor pollution ( $\mathrm{Du}$ et al. 2018); the lower bacterial concentration of outdoor is gained in sunny and snowy day than windy day, for the better disinfection of UV light in sunny day and cleaning the air in snowy day. This may be a means of weather conditions affecting the outdoor bacteria concentration, which affect the indoor air bacteria through natural ventilation. Additionally, the various relative humidity and temperatures have been found to significantly influence airborne bacteria, which would also explain the variation in bacterial concentration with weather conditions.

\subsection{Effects of gender on airborne bacteria in dormitories}

In Fig. 4, the statistical bacterial concentrations (minimum, average and maximum) obtained from ten (after class)). Four similar classrooms (two with southern exposure, two northern) were selected, and each classroom had five sampling points

rooms in the male and female dormitories are displayed at three different sampling times during a typical day which has the similar outdoor environment. Throughout the day, no statistically significant differences were observed in the bacterial concentration in the tested dormitories at the three sampling times at $a>95 \%$ confidence level. The purpose of Fig. 4 is to highlight the impact of gender on the indoor bacterial environment in all the measured dormitories. In the early afternoon, because of similar activities (resting after lunch) on the part of the women and men, the indoor bacterial concentration is approximately the same in both dormitories. According to Luongo et al. (2016a), gender influences indoor bacterial communities significantly. Furthermore, cleaning activities may result in higher bacterial concentrations (Hayleeyesus et al. 2015). As shown in Fig. 4, the average concentrations in the female dormitories in the morning and evening were significantly higher than those in the male dormitories, which might have been due to more numerous material possessions (clothes, dresses, toys and so on) and more frequent cleaning by the women than the men. This finding disagrees with the traditional view that 


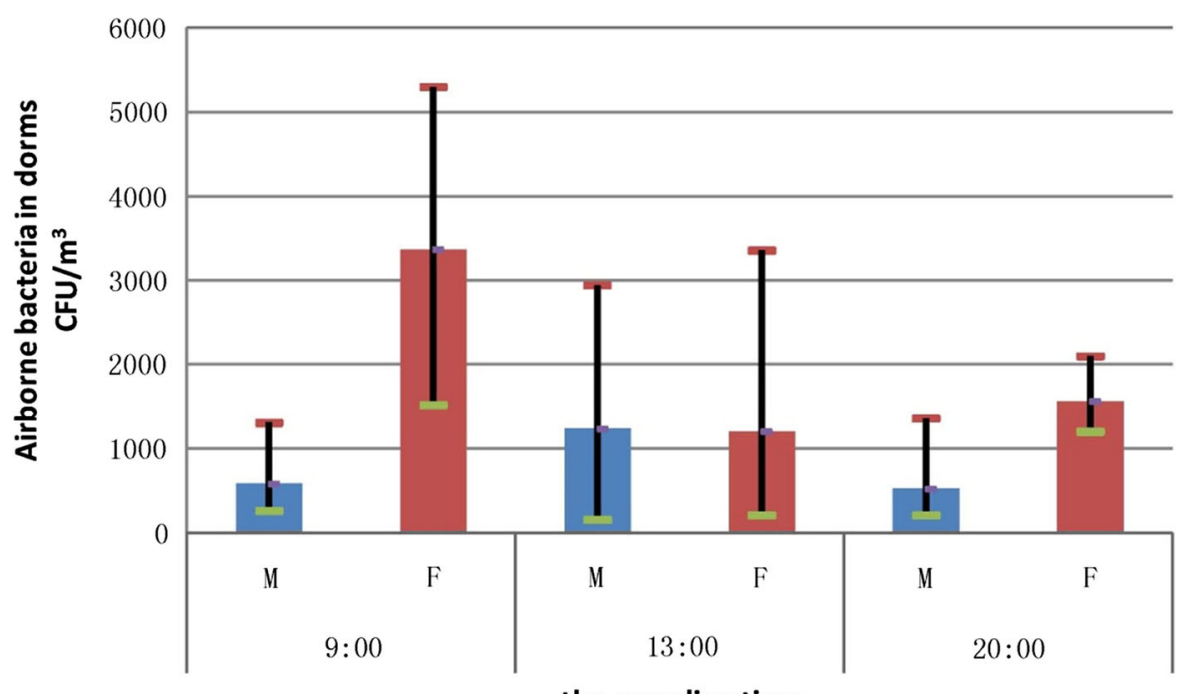

the sampling time

Fig. 4 Maximum, average, and minimum bacterial concentrations in rooms in selected female (F) and male (M) dormitories at different sampling times (9:00, 13:00, 20:00). Five female

microbial contaminant levels in female dormitories would be lower than in male dormitories. Luongo et al. (2016a) have shown that the physiological difference between male and female leads to the significant difference of bacteria species in the dormitory. Different bacteria adapt to different environments; the particularity of the environment sampled in this study is one of the reasons that resulted in the higher bacterial concentration in female dorms than male dorms.

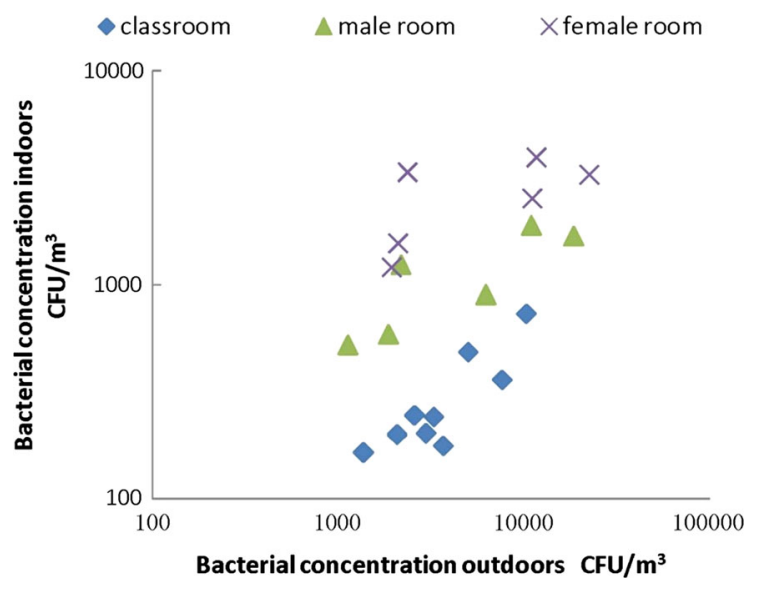

Fig. 5 Indoor and outdoor bacterial concentrations on the campus rooms and five male rooms were tested, and each room had one sampling point with three plates

\subsection{Relationship between indoor and outdoor airborne bacteria}

Figure 5 displays the relationship between indoor and outdoor airborne bacterial concentration in classrooms and dormitory rooms. The outdoor concentration $\left(10^{3}\right.$ to $10^{5} \mathrm{CFU} / \mathrm{m}^{3}$ ) was about ten times greater than the indoor concentration $\left(10^{2}\right.$ to $\left.10^{4} \mathrm{CFU} / \mathrm{m}^{3}\right)$. The indoor bacterial concentration depended strongly on the outdoor concentration (Meadow et al. 2014; Hospodsky et al. 2012), with similar change trends in the classrooms and dormitories, because of the natural ventilation. As a result of human activity and occupants, the indoor bacterial concentration changed more slowly with the outdoor concentration in the dormitories than in the classrooms. For further explanation, the relationship between indoor and outdoor bacteria is defined by Eq. (3) according to the balanced theory (the indoor concentration was equal to the supplying minus the exhausting, plus the internally generating) in a building under stable conditions with steady temperature, $\mathrm{RH}$, air ventilation of indoor environments.

$C_{\mathrm{i}}=\frac{S}{(1+n) V}+\frac{n}{1+n} C_{\mathrm{o}}$. 
$C_{\mathrm{i}}$ and $C_{\mathrm{o}}$ are the bacterial concentration indoors and outdoors, respectively; $S$ is the indoor source; $n$ is the air change rate, which could be estimated by the decay of carbon dioxide; and $V$ is the room volume. Due to more occupants and human activity caused more bacteria as source (Heo et al. 2017), the bacterial concentrations indoors are higher in dormitories than in classrooms at the same outdoors bacterial level. In addition, the less-straight slopes for the dormitories indicate that the ventilation was insufficient when the windows were closed during cold weather.

The relationship between indoor and outdoor bacterial concentration is a common topic in studies of contaminant transport in indoor environments (Blondeau et al. 2005; Viana et al. 2014). Furthermore, the $\mathrm{I} / \mathrm{O}$ ratio, defined as $C_{\mathrm{i}} / C_{\mathrm{o}}$, is an important parameter that gives some indication of the primary source of indoor bacteria. In all the selected indoor environments, the indoor bacterial concentration was significantly lower than that outdoors. Resulted from the less students, poor ventilation and mild activity, the $\mathrm{I} / \mathrm{O}$ ratios for bacteria were far lower than 1.0 for the tested indoor environments, ranging from 0.05 to 0.18 , which indicates that the primary sources may have been penetration airflow through gaps around windows or doors, students' activities, and occupant density. Similar results were obtained by Kim and Kim (2007) and Balasubramanian et al. (2012), who reported that the I/O ratio for bacteria was lower than 1 in various indoor environments. However, the reported I/O values for bacteria are inconsistent with those in other studies by Li et al. (2015) and Mentese et al. (2009), due to higher occupants. Meanwhile, Balasubramanian et al. (2012) found that the I/O ratio was higher than 1 in a bedroom when cleaning activities occurred. Differences in sampling methods,

Table 4 Dose of airborne bacteria in the tested indoor environments (CFU/day)

\begin{tabular}{llll}
\hline & M and F combined & Male (M) & Female (F) \\
\hline Classroom $^{\mathrm{a}}$ & 851 & 931 & 770 \\
Dorm $(m a l e)^{\mathrm{a}}$ & - & 2723 & - \\
Dorm (female) $^{\mathrm{a}}$ & - & - & 3280 \\
Dining hall $^{\mathrm{b}}$ & 739 & 825 & 683 \\
\hline
\end{tabular}

${ }^{\text {a }}$ Sedentary/passive

${ }^{\mathrm{b}}$ Light intensity environmental conditions, greenness, living environment and activities may explain the inconsistencies among the various studies.

\subsection{Dose of airborne bacteria}

The dose of airborne bacteria was estimated for university students in the three typical indoor environments, as listed in Table 4. Because of the wide variety of biological pollutants, which differ from the dose rate verified for the chemical component (Fonseca et al. 2014; Castro et al. 2011), the pathogenic concentration of microbial pollution for different people is unknown. According to the dose rate Eq. 2, the dose of airborne bacteria (CFU/day) is applied to assess the effects of airborne bacteria on people in different indoor environments. The female dormitory represents the worst-case scenario among the four tested locations, presenting the maximum dose of airborne bacteria (3280 CFU/day). Higher dose of airborne bacteria was observed in both the male and female dormitories than in the classroom or dining hall, and the bacterial dose in the classroom and dining hall was similar (Table 4).

The inhalation dose of airborne bacteria for university students was higher in male/female dormitories than in the classroom and dining hall, and this difference is associated with the increased bacterial concentration in dormitories. As expected, the risk of exposure is lower in the larger spaces (classroom and dining hall). In light of the students' higher activity levels and more numerous material possessions in living spaces, the study demonstrated that these spaces are important environments for exposure to bacteria in indoor air. Because the bacterial concentration was measured during daytime hours, students' exposure to airborne bacteria while sleeping was not studied. Thus, the results regarding the dose of airborne bacteria for university students are limited, and it is difficult to calculate the exact evaluation level for health pollution and to compare the information gained with other research (Madureira et al. 2015) because of the different approaches and sampled micro-environments. 


\section{Conclusions}

In this study, the bacterial concentrations were measured and analyzed in 12 university classrooms, 12 dormitory rooms, four bathrooms, and a three-story dining hall. As a result, among the three types of indoor environment, the mean bacterial concentration was highest in the dormitories and lowest in classrooms on the ground floor. One possible explanation for this observation may be the higher occupancy and greater activity level of the students in dormitories. The indoor bacterial concentration varied with the outdoor bacterial concentration. The indoor concentration depended strongly on the outdoor concentration, with similar change trends in the classrooms and dormitories, because of natural ventilation. Considering the students' higher activity level and more numerous material possessions in living spaces, the study demonstrated that these spaces are important environments for exposure to bacteria in indoor air. Students experienced about four times higher dose of airborne bacteria in the dormitories than in the classrooms and dining hall. Because of the unique characteristic of university students, special attention should be paid to the health risks presented by biological pollutants in order to ensure greater efficiency in studying and healthy development for the students.

Acknowledgements This work was financially supported by the National Natural Science Foundation of China (No. 51308372). The authors thank the student occupants and the teachers for their help and cooperation.

\section{References}

Balasubramanian, R., Nainar, P., \& Rajasekar, A. (2012). Airborne bacteria, fungi, and endotoxin levels in residential microenvironments: A case study. Aerobiologia, 28, 375-390.

Bhangar, S., Huffman, J. A., \& Nazaroff, W. W. (2014). Sizeresolved fluorescent biological aerosol particle concentrations and occupant emissions in a university classroom. Indoor Air, 24, 604-617.

Blondeau, P., Iordanche, V., Poupard, O., Genin, D., \& Allard, F. (2005). Relationship between outdoor and indoor air quality in eight French schools. Indoor Air, 15, 2-12.

Castro, D., Slezakova, K., Delerue-Matos, C., Alvim-Ferraz, M. D. C., Morais, S., \& Pereira, M. D. C. (2011). Polycyclic aromatic hydrocarbons in gas and particulate phases of indoor environments influenced by tobacco smoke: Levels, phase distributions, and health risks. Atmospheric Environment, 45, 1799-1808.

Chan, D. W. T., Polly, H. M. L., Cinnie, S. Y. T., \& Jones, A. P. (2008). Survey of airborne bacterial at a University Campus. Indoor and Built Environment, 17, 460-466.

Chatzidiakou, L., Mumovic, D., \& Summerfield, A. J. (2012). What do we know about indoor air quality in school classrooms? A critical review of the literature. Intelligent Buildings International, 4, 228-259.

Daisey, J. M., Angell, W. J., \& Apte, M. G. (2003). Indoor air quality, ventilation and health symptoms in schools: An analysis of existing information. Indoor Air, 13, 53-64.

Despré, V. R., Huffman, J. A., Burrows, S. M., Hoose, C., Safatov, A. S., Buryak, G., et al. (2012). Primary biological aerosol particles in the atmosphere: A review. Tellus $B$, 64(1), 145-153.

Du, P., Du, R., Ren, W., Lu, Z., Zhang, Y., \& Fu, P. (2018). Variations of bacteria and fungi in pm 2.5, in Beijing, China. Atmospheric Environment, 172, 55-64.

Ege, M. J., Mayer, M., Normand, A. C., Genuneit, J., Cookson, W. O. C. M., Braun-Farhlander, C., et al. (2011). Exposure to environmental microorganisms and childhood asthma. New England Journal of Medicine, 364, 701-709.

Emerson, J. B., Keady, P. B., Brewer, T. E., Clements, N., Morgan, E. E., Awerbuch, J., et al. (2015). Impacts of flood damage on airborne bacteria and fungi in homes after the 2013 Colorado Front Range flood. Environmental Science and Technology, 49, 2675-2684.

Faridi, S., Hassanvand, M. S., Naddafi, K., Yunesian, M., Nabizadeh, R., Sowlat, M. H., et al. (2015). Indoor/outdoor relationships of bioaerosol concentrations in a retirement home and a school dormitory. Environmental Science and Pollution Research, 22, 8190-8200.

Fonseca, J., Slezakova, K., Morais, S., \& Pereira, M. C. (2014). Assessment of ultrafine particles in Portuguese preschools: Levels and exposure doses. Indoor Air, 24, 618-628.

Giulio, M. D., Grande, R., Campli, E. D., Bartolomeo, S. D., \& Cellini, L. (2010). Indoor air quality in university environments. Environmental Monitoring and Assessment, 170, 509-517.

Godwin, C., \& Batterman, S. (2007). Indoor air quality in Michigan schools. Indoor Air, 17, 109-121.

Grisoli, P., Rodolfi, M., Chiara, T., Zonta, L. A., \& Dacarro, C. (2012). Evaluation of microbiological air quality and of microclimate in university classrooms. Environmental Monitoring and Assessment, 184(7), 4171-4180.

Hayleeyesus, S. F., Ejeso, A., \& Derseh, F. A. (2015). Quantitative assessment of bio-aerosols contamination in indoor air of university dormitory rooms. International Journal of Health Sciences, 9, 249-256.

Hayleeyesus, S. F., \& Manaye, A. M. (2014). Microbiological quality of indoor air in university libraries. Asian Pacific Journal of Tropical Biomedicine, 4, S312-S317.

Heinrich, J. (2011). Influence of indoor factors in dwellings on the development of childhood asthma. International Journal of Hygiene and Environmental Health, 214, 3-27.

Heo, K. J., Lim, C. E., Kim, H. B., \& Lee, B. U. (2017). Effects of human activities on concentrations of culturable bioaerosols in indoor air environments. Journal of Aerosol Science, 104, 58-65. 
Hospodsky, D., Qian, J., Nazaroff, W. W., Yamamoto, N., Bibby, K., Rismani-Yazdi, H., et al. (2012). Human occupancy as a source of indoor airborne bacteria. PLoS ONE, 7(4), e34867.

ISO. (2013). Microbiology of the food chain-horizontal method for the enumeration of microorganisms-Part 1: Colony count at 30 degrees $\mathrm{C}$ by the pour plate technique (ISO 4833:2013).

Kalwasinska, A., Burkowska, A., \& Wilk, I. (2012). Microbial air contamination in indoor environment of a university library. Annals of Agricultural and Environmental Medicine, 19, 25-29.

Keski-Nisula, L., Katila, M. L., Remes, S., Heinonen, S., \& Pekkanen, J. (2009). Intrauterine bacterial growth at birth and risk of asthma and allergic sensitization among offspring at the age of 15 to 17 years. Journal of Allergy and Clinical Immunology, 123, 1305-1311.

Kim, K. Y., \& Kim, C. N. (2007). Airborne microbiological characteristics in public buildings of Korea. Building and Environment, 42, 2188-2196.

Kim, K. Y., Park, J. B., Jang, G. Y., Kim, C. N., \& Lee, K. J. (2007). Assessment of bioaerosols in the public buildings of Korea. Indoor and Built Environment, 16, 465-471.

Klepeis, N. E., Nelson, W. C., Ott, W. R., Robinson, J. P., Tsang, A. M., Switzer, P., et al. (2001). The national human activity pattern survey (NHAPS): A resource for assessing exposure to environmental pollutants. Journal of Exposure Analysis and Environmental Epidemiology, 11, 231-252.

Li, Y. P., Wang, W., Guo, X., Wang, T. L., Fu, H. L., Zhao, Y., et al. (2015). Assessment of airborne bacteria and fungi in various university indoor environments: A case study in Chang'an University, China. Environmental Engineering Science, 32, 273-283.

Liu, M., Liu, J., Ren, J., Liu, L., Chen, R., \& Li, Y. (2019). Bacterial community in commercial airliner cabins in China. International Journal of Environmental Health Research, 22, 1-12.

Luongo, J. C., Barberán, A., Hacker-Cary, R., Morgan, E. E., \& Fierer, N. (2016a). Microbial analyses of airborne dust collected from dormitory rooms predict the sex of occupants. Indoor Air, 27, 338-344.

Luongo, J. C., Fennelly, K. P., Keen, J. A., Zhai, Z. J., Jones, B. W., \& Miller, S. L. (2016b). Role of mechanical ventilation in the airborne transmission of infectious agents in buildings. Indoor Air, 26, 666-678.

Madureira, J., Paciência, I., Rufo, J. C., Pereira, C., Teixeira, J. P., \& Fernandes, E. (2015). Assessment and determinants of airborne bacterial and fungal concentrations in different indoor environments: homes, child day-care centres, primary schools and elderly care centres. Atmospheric Environment, 109, 139-146.

Meadow, J. F., Altrichter, A. E., Kembel, S. W., Kline, J., Mhuireach, G., Moriyama, M., et al. (2014). Indoor airborne bacterial communities are influenced by ventilation, occupancy, and outdoor air source. Indoor Air, 24, 41-48.

Mendell, M. J., \& Heath, G. A. (2005). Do indoor pollutants and thermal conditions in schools influence student performance? A critical review of the literature. Indoor Air, $15,27-52$.

Mendell, M. J., Mirer, A. G., Cheung, K., Tong, M., \& Douwes, J. (2011). Respiratory and allergic health effects of dampness, mold, and dampness-related agents: A review of the epidemiologic evidence. Environmental Health Perspectives, 119, 748-756.

Mentese, S., Arisoy, M., Rad, A. Y., \& Güllü, G. (2009). Bacteria and fungi levels in various indoor and outdoor environments in Ankara, Turkey. CLEAN-Soil, Air, Water, 37, 487-493.

Mentese, S., \& Tasdibi, D. (2014). Airborne bacteria levels in indoor urban environments: The influence of season and prevalence of sick building syndrome (SBS). Indoor and Built Environment, 25, 563-580.

NSC (National Standard of China). (2002). Indoor air quality standard, GB/T 18883, Beijing, China.

NSC (National Standard of China). (2013). Examination methods for public places-Part 3: Airborne microorganism, GB/T 18204.3, Beijing, China.

Nunes, I., Mesquita, N., Cabo Verd, S., Bandeira, A. M. L., Carolino, M. M., Portugal, A., et al. (2013). Characterization of an airborne microbial community: A case study in the archive of the University of Coimbra, Portugal. International Biodeterioration and Biodegradation, 79, 36-41.

Omeliansky, V. L. (1940). Manual microbiology. Moscow: USSR academy sciences.

Priyamvada, H., Priyanka, C., Singh, R. K., Akila, M., Ravikrishna, R., \& Gunthe, S. S. (2018). Assessment of PM and bioaerosols at diverse indoor environments in a southern tropical Indian region. Building and Environment, 137, 215-225.

Qian, J., Hospodsky, D., Yamamoto, N., Nazaroff, W. W., \& Peccia, J. (2012). Size-resolved emission rates of airborne bacteria and fungi in an occupied classroom. Indoor Air, 22, 339-351.

Sahlberg, B., Gunnbjörnsdottir, M., Soon, A., Jogi, R., Gislason, T., Wieslander, G., et al. (2013). Airborne molds and bacteria, microbial volatile organic compounds (MVOC), plasticizers and formaldehyde in dwellings in three north european cities in relation to sick building syndrome (SBS). Science of the Total Environment, 444, 433-440.

Squinazi, F. (1990). Microbiologic air contamination and building-associated illness. Aerobiologia, 6(1), 45-50.

US EPA. (2011). United States Environmental Protection Agency. Exposure Factors Handbook: 2011 edition.

Viana, M., Rivas, I., Querol, X., Alastuey, A., Sunyer, J., Alvarez-Pedrerol, M., et al. (2014). Indoor/outdoor relationship and mass closure of quasi-ultrafine accumulation and coarse particles in Barcelona schools. Atmospheric Chemistry and Physics, 14, 4459-4472.

Yu, J., Huang, H. J., Jin, F., \& Xu, J. (2011). The role of airborne microbes in school and its impact on asthma, allergy, and respiratory symptoms among school children. Reviews in Medical Microbiology, 22, 84-89. 